Abstracta Iranica

Revue bibliographique pour le domaine irano-aryen

Volume 42-43 | 2021

Comptes rendus des publications de 2019-2020

\title{
Narges Bajoghli. Iran Reframed: Anxieties of Power in the Islamic Republic
}

\section{Laetitia Nanquette}

\section{(2) OpenEdition \\ 1 Journals}

\section{Electronic version}

URL: https://journals.openedition.org/abstractairanica/51891

DOI: 10.4000/abstractairanica.51891

ISSN: 1961-960X

Publisher:

CNRS (UMR 7528 Mondes iraniens et indiens), Éditions de l'IFRI

\section{Electronic reference}

Laetitia Nanquette, "Narges Bajoghli. Iran Reframed: Anxieties of Power in the Islamic Republic", Abstracta Iranica [Online], Volume 42-43 | 2021, document 1, Online since 30 December 2020, connection on 14 December 2022. URL: http://journals.openedition.org/abstractairanica/51891 ; DOI: https://doi.org/ 10.4000/abstractairanica.51891

This text was automatically generated on 14 December 2022.

All rights reserved 


\title{
Narges Bajoghli. Iran Reframed: Anxieties of Power in the Islamic Republic
}

\author{
Laetitia Nanquette
}

\section{REFERENCES}

Narges Bajoghli. Iran Reframed: Anxieties of Power in the Islamic Republic. Stanford Studies in Middle Eastern and Islamic Societies and Cultures. Stanford: Stanford University Press, 2019

1 This book is an ethnographic study of the media producers of the Iranian paramilitary organizations. It investigates the strategies they have developed to court Iranian youth. Over ten years, the author has interviewed the cultural producers of the regime and did long-term participant-observation in regime media studios. She draws the portrait of several of these men and also takes us into the rooms where decisions are made about which media to create for which audience. It shows the complexity of the media branch of the regime, not only the inter-generational conflict but also the conflicts within. The author powerfully demonstrates how some of these men have evolved and become pragmatic. Their rallying point is to save the nezam (regime) but they are quite flexible as to how to approach this goal. On the other side, the third generation who joins the paramilitary organizations is opportunistic and often uses the basij to climb the social ladder.

2 This book is an excellent read for scholars working on contemporary Iran or on the media. It is written in an accessible language, that makes it also a great read for a general audience wanting to know about Iran politics in its complexity. 


\section{AUTHORS}

\section{LAETITIA NANQUETTE}

University of New South Wales, Sydney 